\title{
The Nascent International Law on Most-Favoured-Nation (MFN) Clauses in Bilateral Investment Treaties (BITs)
}

\author{
Andreas R. Ziegler
}

\section{Introduction}

\begin{abstract}
The divergent interpretations of the most-favoured-nation clause continue to cause difficulties, and it may be necessary to reconsider the view expressed by the League of Nations Committee of Experts that the subject, which it discussed in detail on the basis of a thorough report, can be best dealt with by way of bilateral agreements. ${ }^{1}$

[T] he "law" on MFN clauses is, in part, in a nascent stage of development — which is why there are such divergent responses by different ad hoc Committees to different MFN Clauses (and sometimes even similarly worded MFN clauses) in Bilateral Investment Treaties. $^{2}$
\end{abstract}

Despite early calls after World War II for a need to clarify the scope of MFN clauses in international treaties, this general debate remained rather silent since the International Law Commission suspended its work on the issue in the mid 1970 s. $^{3}$ With regard to bilateral investment treaties (BITs), clauses relating to Most-Favoured-Nation (MFN) treatment did not give rise to any particular

\footnotetext{
A.R. Ziegler

Universität Lausanne, Lausanne, Switzerland e-mail: andreas.ziegler@unil.ch

${ }^{1}$ United Nations, Memorandum submitted by the Secretary-General, "Survey of International Law in Relation to the Work of Codification of the International Law Commission", extract from the Book of the ILC 1949. Document A/CN.4/1/Rev.1, para. 91, United Nations Publications, 1948. Vol. 1, pp. 52-53.

${ }^{2}$ Wintershall Aktiengesellschaft v. Argentine Republic, ICSID Case No. ARB/04/14 (Germany/ Argentina BIT), Award, 8 December 2008, para. 92. See on this decision L. Peterson, Investment Arbitration Reporter, 1 (2008) 16, p. 11, online at http://www.iareporter.com (last visited 4 January 2009).

${ }^{3}$ It was recently suggested that this work should be resumed in the ILC. For a historic overview, see Ziegler, Most-Favoured Nation (MFN) Treatment, in: Reinisch (ed.), Standards of Investment Protection, 2008, pp. 29-86.
} 
questions until very recently. ${ }^{4}$ These clauses were normally considered as a relic of the traditional way of negotiating establishment and treatment rights for foreign investors in the nineteenth century.

Only very recently, the scope of the MFN treatment clauses has become of interest to arbitrators and legal scholars. ${ }^{5}$ It is especially the question whether the clause applies also to procedural rights (in particular dispute settlement) and definitions (e.g. the definition of a foreign direct investment or a foreign investor) that remains controversial. This discussion is very different from the more substantive discussion in other areas of international economic law, e.g. in relation to trade under the General Agreement on Tariffs and Trade (GATT), the General Agreement on Trade in Services (GATS) or to trade-related aspects of intellectual property rights under the TRIPs-Agreement of the World Trade Organization (WTO). ${ }^{6}$

This article tries to give an overview on the practice of (arbitral) tribunals in this field. In order to do so, it looks first at the main types of MFN clauses as currently found in BITs of major players in this field. It then proceeds to an overview of the topical arbitration awards up to December 2008. The following section will try to classify the existing awards and the opinions expressed therein relating to the proper application of MFN clauses in investment agreements. An outlook on the open issues and questions taking into account the most recent developments in academia and international negotiations will conclude this contribution.

\section{Main Types and Economic Foundation of MFN Treatment}

Most-favoured-nation treatment is treatment accorded by the granting State to the beneficiary State, or to persons or things in a determined relationship with that State, not less favourable than treatment extended by the granting State

\footnotetext{
${ }^{4}$ See, on the MFN clause in the area of Foreign Direct Investment (FDI) in general: UNCTAD, Most-Favoured-Nation Treatment, Series on Issues on International Investment Agreement Series, Document UNCTAD/ITE/IIT/10 (Vol. III), 1999, based on a manuscript prepared by J. Karl.

${ }^{5}$ For very recent examples, see Egli, Don't Get Bit: Addressing ICSID's Inconsistent Application of Most-Favored-Nation Clauses to Dispute Resolution Provisions, Pepperdine Law Review 34 (2007), pp. 1045 ff.; Vesel, Clearing a Path Through a Tangled Jurisprudence: Most-Favored-Nation Clauses and Dispute Settlement Provisions in Bilateral Investment Treaties, The Yale Journal of International Law 32 (2007), pp. 125 ff.; Chukwumerije, Interpreting Most-Favoured-Nations Clauses in Investment Treaty Arbitrations, The Journal of World Investment and Trade 8 (2007), pp. 597 ff.; see also earlier Freyer/Herlihy, Most-Favored-Nation Treatment and Dispute Settlement in Investment Arbitration: Just How "Favored" is "Most-Favored"? ICSID Review — Foreign Investment Law Journal 20 (2005), pp. 58 ff.; Hsu, MFN and Dispute Settlement — When the Twain Meet, The Journal of World Investment and Trade 7 (2006), pp. 25 ff.; Orrego Vicuña, Bilateral Investment Treaties and the Most-Favored-Nation Clause: Implications for Arbitration in the Light of a Recent ICSID Case, in: Kaufmann-Kohler (ed.), Investment Treaties and Arbitration: ASA Swiss Arbitration Association Conference in Zurich of January 25, 2002, 2002, pp. $133 \mathrm{ff}$.

${ }^{6}$ For an overview see also Acconci, Most-Favoured Nation Treatment and International Law on Foreign Investment, in: Muchlinski/Ortino/Schreuer (eds.), The Oxford Handbook of International Investment Law, 2008, pp. 363-407.
} 
to a third State or to persons or things in the same relationship with that third State. ${ }^{7}$

A most-favoured-nation treatment clause per se entails international obligations and rights not only among the Contracting States of the international treaty incorporating it (often referred to as "the basic treaty"), but also among these Contracting States and other States (often referred to as "the third-party treaty") by virtue of different international treaties. Therefore, a most-favoured-nation treatment clause is not only a normal treaty clause, but also a source of international obligations other than those explicitly included in the basic treaty. It allows "borrowing" treaty provisions from other treaties or possibly State practice regarding third States. The material scope of MFN is thus open as the contents of future treaties and state practice cannot be totally foreseen and identified when the basic treaty is concluded. Even with regard to existing treaty obligations in relation to third States, it may be that negotiators are not always completely aware of them. ${ }^{8}$

By its very nature, the MFN clause is different from other international obligations that are usually agreed upon as it seems at first view contrary to the general principle of treaty negotiations that normally a treaty does not create either obligations or rights for a third State without its consent, as enshrined also in Article 34 of the United Nations (Vienna) Convention on the Law of Treaties. ${ }^{9}$ However, a closer analysis shows that MFN is in conformity with the principle that the consent of a State can lead to the creation of new rights as a consequence of a treaty between third States (Article 36 of the Vienna Convention) although it is not a requirement that the contracting States of the later treaty intended the provision to accord that right also to the third State. More importantly, one can say that with regard to MFN treatment the new right is not created by the new treaty but was already encompassed under the basic treaty, and thus is not a case of the application of the rules covered by Part III Section 4 of the Vienna Convention on the Law of Treaties. As a matter of fact, the 1969 Vienna Convention left this issue basically untouched, thereby justifying the ongoing work of the ILC in this context. ${ }^{10}$

In the case of the MFN clause, the basic treaty becomes a dynamic source of law, in so far as the practice of either Party, in particular with regard to later treaties, in

\footnotetext{
${ }^{7}$ See Article 5 Draft Articles on Most-Favoured-Nation Clauses (1978), International Law Commission, as available online at http://untreaty.un.org/ilc/texts/instruments/english/draft\%20articles/1_3_1978.pdf (last visited on 4 January 2009).

${ }^{8}$ See International Law Association, Report of the Committee on Foreign Direct Investment presented at the Biennial Meeting 2008, Section B4, forthcoming 2009.

${ }^{9} 1155$ U.N.T.S. 331, reprinted also in 8 International Legal Materials (1969) 679; signed in Vienna 23 May 1969, entry into force: 27 January 1980.

${ }^{10}$ See Article 5 Draft Articles on Most-Favoured-Nation Clauses (1978), International Law Commission, as available online at http://untreaty.un.org/ilc/texts/instruments/english/draft\% 20articles/1_3_1978.pdf (last visited on 4 January 2009) and Acconci, Most-Favoured Nation Treatment and International Law on Foreign Investment, in: Muchlinski/Ortino/Schreuer (eds.), The Oxford Handbook of International Investment Law, 2008, pp. 363-407 with reference to para. 59 of the Rapport de la Commission à l'Assemblée générale sur les travaux de sa trentième session, p. 16.
} 
relation to the basic treaty becomes of relevance to existing rights and duties under the basic treaty. The MFN clause thus constitutes a prior consent to extend favours extended to third States to the Contracting Parties of the basic treaty.

It is important to note that the MFN principle does not require identical treatment but "treatment at least as favourable". Often, this will mean identical treatment as any other treatment would lead to new problems in relation to third states, but it may also lead to a better treatment or different treatment that is considered to be qualitatively identical or at least as favourable as the treatment of third parties. This distinction may be of lesser importance in the area of investment but can be important when it comes to tariff concessions in the area of trade.

This very nature of the MFN principle is obviously also contrary to a strict application of the reciprocity principle so cherished by states in their traditional diplomatic relations. ${ }^{11}$ While, normally, states will grant each other MFN treatment, the material content of this provision may differ from the beginning or, especially, change over time. This is the main reason why some politicians and even lawyers have always been critical of the MFN clause. They consider it to be a disincentive to negotiate mutually acceptable improvements in their relations, e.g. investment or trade, as one party may benefit from improvement only made by the other party without having to improve its own standards. It can thus lead to so-called free rider effects. MFN clauses are only reciprocal in the sense that they are reciprocally granted but their content is open to divergences and dynamic developments and thus not subject to the reciprocal granting of identical treatment and market access rights.

One way to limit these effects of the MFN principle is to make it not automatic or unconditional but conditional (conditional MFN treatment). An alternative is to provide explicit (temporary) exceptions. This has been discussed ${ }^{12}$ in particular with regard to tariff concessions before WW II, but also with regard to more recent negotiations such as under the GATS. ${ }^{13}$ Conditional MFN treatment normally means that the application of new, more favourable rules or preferences is only granted to existing treaty partners if they agree to apply the same rules; conditional MFN treatment therefore is basically a right to obtain more favourable treatment upon condition of doing the same (reciprocity) while unconditional MFN treatment requires no renewed commitment by the beneficiary. Economic theory, especially in the field of trade, has shown that liberalization, even unilateral, is more likely to lead to increased welfare, and hence often recommends unconditional MFN treatment. ${ }^{14}$ Generally, MFN clauses found in modern BITs are

\footnotetext{
${ }^{11}$ See for example Lo, The Reciprocity Principle in the International Regulation of Economic Relations (Typescript (photocopy), Thesis (S.J.D.) Harvard Law School, 1989, available at http:// de.scientificcommons.org/4449832 (last visited on 4 January 2009).

${ }^{12}$ See for example Wolf, Vorwort, in: Glier (ed.) Die Meistbegünstigungsklausel, 1905, p. v.

${ }^{13}$ Article II:2 GATS; see in this respect Lowenfeld, International Economic Law, 2002, p. 117.

${ }^{14}$ See for an overview on recent economic studies in this field Zarazaga, Measuring the benefits of unilateral trade liberalization; part 2: dynamic models, Economic and Financial Policy Review Issue Q1 (2000), pp. 29-39.
} 
unconditional $^{15}$ but they may be limited in scope and/or subject to exceptions. The basic problem of developing a coherent theory in view of the existing case law stems from the fact that the clauses at stake were often very differently phrased. While they all fall into the same category, their wording allows (at least) technically for differentiation with regard to their scope. ${ }^{16}$

\section{Important Investment Arbitration Awards Relating to MFN}

The MFN clause has been rediscovered in the context of international investment arbitration following the decision of an arbitral tribunal in the case Maffezini v. Spain $^{17}$ in 2000 . Since then a number of tribunals have had to address the issue of the correct application and interpretation of the MFN clause. ${ }^{18}$

\footnotetext{
${ }^{15}$ See also Acconci, Most-Favoured Nation Treatment and International Law on Foreign Investment, in: Muchlinski/Ortino/Schreuer (eds.), The Oxford Handbook of International Investment Law, 2008, pp. 363-407, Section 3.

${ }^{16}$ See the diverging case law as reported in the next section and, for details, Acconci, MostFavoured Nation Treatment and International Law on Foreign Investment, in: Muchlinski/Ortino/ Schreuer (eds.), The Oxford Handbook of International Investment Law, 2008, pp. 363-407, Section 3.1, who rightly refers to Anzilotti, Cours de droit international, 1929, pointing out that “... juridiquement parlant, il n'existe pas une clause de la nation la plus favorisée; il existe autant de stipulations distinctes qu'il y a de traités qui la contiennent, de sorte que toute question relative à la nature et aux effets de la clause est avant tout une question d'interprétation d'une clause donnée dans un traité déterminé" (at 438). See also Dolzer and Myers, After Tecmed: MostFavored-Nation Clauses in Investment Protection Agreements, ICSID Review - Foreign Investment Law Journal 19 (2004), p. 49 (50 ff.); Gaillard, Establishing Jurisdiction through a Most-Favored-Nation Clause, New York Law Journal (June 2005) p. 8; for an overview over existing examples see UNCTAD, Recent Developments in International Investment Agreements, UNCTAD/WEB/ITE/IIT/2005/1, 30 August 2005 and UNCTAD, International Investment RuleSetting: Trends, Emerging Issues and Implications, TD/B/COM.2/68, 18 January 2006.

${ }^{17}$ ICSID Case No. ARB/97/7, Maffezini v. Spain, Decision on Jurisdiction, 24 January 2000, paras. $53 \mathrm{ff}$. This and all other awards mentioned in this article are available online at http://ita.law.uvic. ca/index.htm (last visited on 4 January 2009). See immediately below point 3 in main text for details. For comments, see Fietta, Most Favoured Nation Treatment and Dispute Resolution under Bilateral Investment Treaties: a Turning Point? International Arbitration Law Review (2005) pp. 131-138; Liberti, Arbitrato ICSID, clausola della nazione più favorita e problemi di attribuzione, Rivista dell'arbitrato (2004), pp. $580 \mathrm{ff}$.

${ }^{18}$ For an overview on the case law see Houde/Pagani, Most Favoured Nation Treatment in International Investment Law, in: OECD (ed.), International Investment Law: A Changing Landscape - A Companion Volume to International Investment Perspectives, 2005, Chap. 4; Teitelbaum, Who's Afraid of Maffezini? Recent Developments in the Interpretation of MostFavored-Nation Clauses, Journal of International Arbitration 22 (2005), pp. 225-238; Acconci, Most-Favoured-Nation Treatment and International Law on Foreign Investment, in: Muchlinski/ Ortino/Schreuer (eds.), The Oxford Handbook of International Investment Law, 2008, pp. 363-407; Reinisch, "Maffezini v. Spain Case”, in: Encyclopaedia of Public International Law - EPIL, forthcoming 2010.
} 
The following section provides a very short overview of the most relevant cases with respect to their contribution to discussion of MFN treatment in order to facilitate later discussion of the specific issues addressed:

1. Asian Agricultural Products Ltd. (APPL) v. Sri Lanka (1990). In this first ICSID case relating to an arbitration clause contained in a BIT (1980 BIT between the UK and Sri Lanka), Article 3 of the agreement provided for most-favourednation treatment which, according to the investor, allowed for the incorporation of the liability standards (no "war clause" and no "civil disturbance exemption") contained in the 1981 BIT between Switzerland and Sri Lanka, as they were more favourable than those contained in the UK-Sri Lanka BIT. The ICSID Tribunal rejected this claim, by establishing that it was not clear that the Sri Lanka-Switzerland Treaty contained more favourable provisions. ${ }^{19}$

2. Pope and Talbot v. Canada (1999). A US investor had originally invoked the MFN treatment clause of NAFTA (Article 1103) against Canada in order to be given the "fair and equitable treatment" as contained in various BITs concluded by Canada with third States which might go beyond what is contained in Article 1105 NAFTA (Minimum Standard of Treatment). The claim was later dropped and therefore not assessed substantively by the tribunal. ${ }^{20}$

3. Maffezini v. Spain (2000). An Argentinean investor in Spain requested the application of the MFN clause contained in Article IV (2) of the Spain-Argentina BIT to benefit from the allegedly more favourable provision in the Chile-Argentina BIT (no waiting period of 18 months until arbitral tribunal can be seized). The tribunal rejected Spain's argument that the application of the MFN clause was limited to substantive matters or material aspects of the treatment granted to investors and did not cover procedural or jurisdictional questions. ${ }^{21}$

\footnotetext{
${ }^{19}$ ICSID Case No. ARB/87/3, AAPL v. Sri Lanka, Award of 27 June 1990, para. 54. On this award, see Acconci, Most-Favoured-Nation Treatment and International Law on Foreign Investment, in: Muchlinski/Ortino/Schreuer (eds.), The Oxford Handbook of International Investment Law, 2008, pp. 363-407, Sect. 4.1; Manciaux, Investissements étrangers et arbitrage entre États et ressortissants d'autres États, 2004, pp. 582-585.

${ }^{20}$ Pope \& Talbot Inc. v. The Government of Canada, UNCITRAL (NAFTA), Procedural Order No. 2, 28 October 1999, as referred to in Kinnear/Bjorklund/Hannaford, Investment Disputes under NAFTA - An Annotated Guide to NAFTA Chapter 11, 2006, pp. 1103-1109. See also Acconci, Most-Favoured Nation Treatment and International Law on Foreign Investment, in: Muchlinski/ Ortino/Schreuer (eds.), The Oxford Handbook of International Investment Law, 2008, pp. 363-407, Sect. 4.2.

${ }^{21}$ ICSID Case No. ARB/97/7, Maffezini v. Spain, Decision on Jurisdiction, 24 January 2000, paras. $53 \mathrm{ff}$; and on this award, among others, Acconci, Most-Favoured Nation Treatment and International Law on Foreign Investment, in: Muchlinski/Ortino/Schreuer (eds.), The Oxford Handbook of International Investment Law, 2008, pp. 363-407, Sects. 4.2 and 5.1. For a critical assessment of the Maffezini award, see Fietta, Most Favoured Nation Treatment and Dispute Settlement Resolution Under Bilateral Investment Treaties: A Turning Point, International Arbitration Law Review 8 (2005) pp. 131 ff.; for a more favourable assessment see Boscariol/Silva, The Widening Application of the MFN Obligation and its Impact on Investor Protection, International Trade Law and Regulation 11 (2005), pp. $61 \mathrm{ff}$.
} 
4. ADF v. USA (2003). A Canadian investor invoked the MFN clause contained in Article 1103 NAFTA in order to benefit from the allegedly further-reaching protection in the US-Estonia and US-Albania BITs (fair and equitable treatment), similar to the original claims presented in Pope \& Talbot v. Canada (2001/2). The tribunal concluded that even if the United States had granted a better protection under the respective BITs (which seemed doubtful to the tribunal) the US was not in breach of this standard. ${ }^{22}$

5. The Loewen Group, Inc., Raymond L. Loewen v. The United States of America (2003). NAFTA's most-favoured-nation treatment clause (Article 1103) was invoked to avoid the requirement of maintaining " "continuous nationality' during investment disputes" which allegedly was not necessary under other BITs concluded by the US. The ICSID Tribunal did not address this claim and upheld the US's objection to its jurisdiction due to the lack of the claimant's continuous nationality. ${ }^{23}$

6. Yaung Chi Oo (YCO) Trading Pte Ltd. v. Myanmar (2003). Myanmar was not a member of ASEAN at the time YCO (an investor from Singapore) had entered a joint venture with Myanmar Foodstuff Industries and the State Industrial Organization of Myanmar. Myanmar acceded to the 1987 ASEAN Agreement only in July 1997 and became a party to the 1998 Framework Agreement for ASEAN Investment. YCO, inter alia, claimed that the ASEAN Arbitral Tribunal had jurisdiction under the 1998 Framework Agreement (to which both Singapore and Myanmar were parties) relating to measures taken before 1998 by invoking the most-favoured nation provision of Article 8, citing more favourable treatment to investors under the 1998 Philippines-Myanmar Bilateral Investment Treaty ("BIT") (consent to international arbitration). The Tribunal declined jurisdiction on this ground, noting that the Claimant had failed to invoke the MFN clause at the initiation of arbitration proceedings. It further observed that, in any event, there was no indication that there would be arbitral jurisdiction under any BIT entered into by Myanmar under the present facts. The Tribunal therefore concluded that it was unnecessary for it to consider jurisdiction under the 1998 Framework Agreement. $^{24}$

7. Tecmed v. Mexico (2003). A Spanish investor tried to overcome jurisdictional limitations ratione temporis by invoking an MFN clause in the Mexico-Spain BIT of 1995, and thereby borrowing the more generous clause on temporal scope in the

\footnotetext{
${ }^{22}$ ICSID Case No. ARB (AF)/00/1 (NAFTA), ADF Group Inc. v. United States, Award, 9 January 2003, paras. 193 ff.; see also Acconci, Most-Favoured Nation Treatment and International Law on Foreign Investment, in: Muchlinski/Ortino/Schreuer (eds.), The Oxford Handbook of International Investment Law, 2008, pp. 363-407, Sect. 4.2.

${ }^{23}$ ICSID Case No. ARB(AF)/98/3, The Loewen Group, Inc., Raymond L. Loewen v. The United States of America, Award of 26 June 2003, in particular at para. 225. See also Raymond L. Loewen v. The United States of America, Petition to Vacate of 13 December 2004, footnote 2. On 31 October 2005, the US District Court for the District of Columbia denied this petition.

${ }^{24}$ ASEAN I.D. Case No. ARB/01/1, Yaung Chi Oo Trading Pte Ltd. v. Myanmar, Award of 31 March 2003; see also Acconci, Most-Favoured Nation Treatment and International Law on Foreign Investment, in: Muchlinski/Ortino/Schreuer (eds.), The Oxford Handbook of International Investment Law, 2008, pp. 363-407, Sect. 5.3.
} 
1998 BIT between Mexico and Austria. The ICSID tribunal did not allow the retroactive application of substantive standards as contained in this treaty with a third party "because it deem[ed] that matters relating to the application over time of the Agreement [...] due to their significance and importance, go to the core of matters that must be deemed to be specifically negotiated by the Contracting Parties". 25

8. MTD v. Chile (2004). The Malaysian company MTD Equity Sdn Bhd. had invoked the MFN clause contained in the Chile-Malaysia BIT in order to benefit from two other BITs concluded by Chile with Denmark and Croatia which contained more detailed treaty language on "fair and equitable treatment", including obligations to award permits subsequent to the approval of an investment, the prohibition of Unreasonable and Discriminatory Measures, and the fulfilment of contractual obligations (umbrella clause), respectively. The tribunal agreed to incorporate the provisions of the Croatian and Danish treaties into the Treaty between Malaysia and Chile by virtue of the "wide scope" of the latter treaty's MFN clause, deeming this importation to be "in consonance with" the purpose of the Malaysia-Chile investment treaty. ${ }^{26}$

9. Siemens v. Argentina (2004). The investor, the German company Siemens, invoked the more favourable terms of a bilateral investment treaty (absence of a waiting period of 18 months before an arbitral tribunal can be seized) between Argentina and Chile - by virtue of the MFN clause contained in the GermanyArgentina BIT. Argentina objected to Siemens' failure to exhaust an 18-month time period set out in the Germany-Argentina BIT for recourse to local courts, prior to turning to international arbitration. The arbitral tribunal determined that the relevant MFN clause allowed the investor to choose more favourable dispute settlement provisions from various other agreements. ${ }^{27}$

10. Salini v. Jordan (2004). The Italian investor invoked the MFN clause in the BIT between Jordan and Italy in order to benefit from more favourable dispute settlement provisions in the BITs with the US and the UK. In the view of the claimants, the US and UK treaties contained a dispute settlement clause "which is more favourable than that contained in Article 9 of the Jordan-Italy BIT", by virtue of its supposed inclusion of contractual breaches. The relevant MFN clause was silent on the question of the application of MFN to the dispute settlement process;

\footnotetext{
${ }^{25}$ ICSID Case No. ARB/AF/00/2, Technicas Medioambientales Tecmed S.A. v. Mexico, Award, 29 May 2003, para. 69.

${ }^{26}$ ICSID Case No. ARB/01/7, MTD Equity Sdn. Bhd. and MTD Chile S.A. v. Republic of Chile, Award, 25 May 2004, para. 103; see the comments by L. Peterson, Malaysian firm wins BIT case against Chile; "wide scope" of MFN clause looms large, INVEST-SD: Investment Law and Policy Weekly News Bulletin, 23 August 2004, published by the International Institute for Sustainable Development, available online at http://www.iisd.org/investment. The annulment decision regarding this award is of minor importance with regard to the findings on MFN; see Decision on Annulment, 21 March 2007. para. 64.

${ }^{27}$ ICSID Case No. ARB/02/8, Siemens A.G. v. The Argentine Republic, Decision on Jurisdiction, 3 August 2004.
} 
accordingly, the tribunal rejected the claimants' contention that the MFN clause should be interpreted so as to apply to procedural matters. ${ }^{28}$

11. Lucchetti v. Peru (2005). The claim concerned how the Respondent State, Peru, had applied the fair and equitable treatment standard, national treatment and most-favoured-nation treatment. According to the claimant, Peru had breached all of its treatment obligations provided in the 2000 BIT between Chile and Peru. ${ }^{29}$ The ICSID Tribunal did not address the issue as it declined jurisdiction.

12. Plama v. Bulgaria (2005). The tribunal refused to permit the Cypriot investor to invoke the MFN clause contained in the BIT between Bulgaria and Cyprus in order to borrow the arbitration clause found in another investment treaty by Bulgaria, which would have paved the way for arbitration under a different set of rules and over a much broader range of claims. ${ }^{30}$

13. CMS v. Argentina (2005). The investor relied on the most-favoured-nation treatment clause included in the 1991 BIT between the United States and Argentina to maintain that the liability standards (no exceptions) incorporated in other BITs concluded by Argentina should apply. The Tribunal rejected this assertion since it was "not convinced that the clause [had] any role to play in this case". The Tribunal established that such an assertion would in any event fail under the ejusdem generis rule. $^{31}$

14. Impregilo S.p.A. v. Pakistan (2005). The Italian investor claimed that by applying the MFN clause in the 1997 Italy and Pakistan BIT, it was entitled to request ICSID arbitration in relation to contractual claims covered under the so-called "umbrella clauses", such as contained in the 1995 Switzerland and Pakistan BIT. The Italy-Pakistan BIT did not provide for the coverage of purely contractual claims as investment claims. Although the Tribunal ultimately held that the claims were not claims against Pakistan as a party to the agreement but against a separate entity, it did not exclude the possibility of invoking the umbrella clause on the basis of the MFN clause: "even assuming arguendo that Pakistan, through the MFN clause and the Swiss-Pakistan BIT, has guaranteed the observance of the contractual commitments into which it has entered together with Italian investors, such a guarantee would not cover the present Contracts - since they are agreements into which it has not entered". 32

\footnotetext{
${ }^{28}$ ICSID Case No. ARB/02/13, Salini Costruttori S.p.A and Italstrade S.p.A v. The Hashemite Kingdom of Jordan, Decision on Jurisdiction, 29 November 2004.

${ }^{29}$ ICSID Case No. ARB/03/4, Empresas Lucchetti, S.A. and Lucchetti Peru, S.A. v. Republic of Peru, Decision on Jurisdiction, 7 February 2005, para. 23.

${ }^{30}$ ICSID Case No. ARB/03/24, Plama Consortium Ltd. v. Bulgaria, Decision on Jurisdiction, 8 February 2005. See also Acconci, Most-Favoured Nation Treatment and International Law on Foreign Investment, in: Muchlinski/Ortino/Schreuer (eds.), The Oxford Handbook of International Investment Law, 2008, pp. 363-407, Sect. 5.3.

${ }^{31}$ ICSID Case No. ARB/01/8, CMS Gas Transmission Co. v. Argentina, Award of 20 April 2005, para. 377. On the ejusdem generis principle, see next section.

${ }^{32}$ ICSID Case No. ARB/03/3, Impregilo S.p.A. v. Pakistan, Decision on Jurisdiction of 22 April 2005, para. 223.
} 
15. Camuzzi v. Argentina (2005). In this case, Argentina did not object at all to the claimant's attempt to refer to the MFN clause included in the 1990 BIT between Argentina and the Belgo-Luxembourg Economic Union (the basic treaty) in order to borrow a more favourable dispute settlement clause (no waiting period) provided by the 1991 US-Argentina BIT. In view of Argentina's missing objection, the ICSID Tribunal did not "decide on the relevance of that clause" in the case. However, for the sake of clarity, the Tribunal specified that Argentina had probably considered the "18 months in domestic courts" requirement met, since Camuzzi had "submitted the dispute to [its] national courts" which had left it unresolved. ${ }^{33}$

16. Gas Natural v. Argentina (2005). An investor invoked the MFN clause contained in the 1991 Agreement between Argentina and Spain in order to borrow the allegedly more favourable dispute settlement provisions in several BITs concluded by Argentina with third states. The Gas Natural tribunal followed the Maffezini approach stating that there was "no 'public policy' reason not to give effect to the most-favoured-nation provision with respect to the right to proceed directly to international arbitration" ${ }^{34}$ because the applicable MFN clause related to "all matters" and thus covered dispute settlement. In the tribunal's view "assurance of independent international arbitration is an important — perhaps the most important - element in investor protection". 35

17. Bayindir v. Pakistan (2005). The 1995 BIT between Turkey and Pakistan did not expressly include a fair and equitable treatment clause. The investor asserted that he was entitled to such a treatment as provided in other treaties entered into by Pakistan through the MFN clause. The ICSID Tribunal accepted jurisdiction with regard to this request as other BITs concluded by Pakistan contained "an explicit fair and equitable treatment clause". 36 The claimant had also contended a direct violation of the most-favoured-nation clause included in the Turkey and Pakistan BIT as Pakistan had engaged in a selective tendering process allegedly intended to squeeze Bayindir out of the market. In this respect the Tribunal equally confirmed its jurisdiction. ${ }^{37}$

\footnotetext{
${ }^{33}$ ICSID Case No. ARB/03/2, Camuzzi International S.A. v. Argentina, Decision on Objections to Jurisdiction of 11 May 2005, para. 121. See, for details, Acconci, Most-Favoured Nation Treatment and International Law on Foreign Investment, in: Muchlinski/Ortino/Schreuer (eds.), The Oxford Handbook of International Investment Law, 2008, pp. 363-407, Sect. 5.1.

${ }^{34}$ ICSID Case No. ARB/03/10, Gas Natural SDG, S.A. v. Argentina, Decision on Preliminary Questions on Jurisdiction, 17 June 2005, para. 28. See on this case, among others, Reinisch, Maffezini v. Spain Case, in: Encyclopaedia of Public International Law - EPIL, forthcoming 2010.

${ }^{35}$ Ibid., para. 49.

${ }^{36}$ ICSID Case No. ARB/03/29, Bayindir Insaat Turizm Ticaret Ve Sanayi A.Ş. v. Pakistan, Decision on Jurisdiction of 14 November 2005, para. 231.

${ }^{37}$ Ibid. Para. 206 reads: "The mere fact that Bayindir had always been subject to exactly the same legal and regulatory framework as everybody else in Pakistan does not necessarily mean that it was actually treated in the same way as local (or third countries) investors. In other words, as is evident from the broad wording of Article II (2) of the BIT, the treatment the investor is offered under the MFN clause is not limited to 'regulatory treatment"'. Para 223 reads: "The fact remains that, taken
} 
18. Continental Casualty v. Argentina (2006). Argentina objected to ICSID jurisdiction based on the MFN clause in the 1991 BIT between Argentina and the United States. As the claimant only used this provision in order to get better substantive treatment (the treatment granted to investors as to the remittance of capital transfers) and not procedural improvements, the ICSID Tribunal accepted jurisdiction in view of possibly applying the MFN clause with regard to the allegedly discriminatory treatment relating to to the remittance of capital transfers. ${ }^{38}$

19. National Grid Transco plc v. Argentina (2006). In this case again, the 18-month waiting period before an arbitral tribunal can be seized (as contained in the 1990 UK-Argentina BIT) was removed by an UNCITRAL tribunal by allowing the investor from the United Kingdom to rely on the more favourable provision in the Argentina-US BIT. ${ }^{39}$

20. Telenor v. Hungary (2006). The investor referred to the MFN clause included in the 1991 Norway-Hungary BIT and asked for the incorporation of more favourable dispute settlement provisions in other agreements concluded by Hungary which allowed for a more generous jurisdiction of an ICSID tribunal (not limited to expropriation claims as in the 1991 Norway-Hungary BIT). The tribunal refused such incorporation. ${ }^{40}$

21. Suez, Sociedad General de Aguas de Barcelona S.A., and Vivendi Universal S.A. v. Argentina and AWG Group Ltd. v. Argentina (2006). In this case, immediate access to an ICSID arbitral tribunal for British and Spanish investors was achieved through the most-favoured-nation clauses included in the basic treaties (the 1990 Argentina and the United Kingdom BIT and the 1991 Argentina and Spain BIT). The dispute settlement clause of the 1991 Argentina and France BIT, according to which no prior litigation in local courts was necessary, was borrowed again as being a more favourable treatment. ${ }^{41}$

22. Berschader v. Russia (2006). An arbitral tribunal at the Stockholm Arbitration Institute declined jurisdiction to hear a claim by two Belgian businessmen brought pursuant to the USSR-Belgium bilateral investment treaty. The tribunal noted that the relevant dispute settlement provision in the BIT originally concluded between the USSR and Belgium was rather narrow, and permitted

together, Bayindir's allegations in respect of the selective tender, and that the expulsion was due to Pakistan's decision to favor a local contractor, and that the local contractor was awarded longer completion time-limits, if proven, are clearly capable of founding a MFN claim".

${ }^{38}$ ICSID Case No. ARB/03/9, Continental Casualty Co. v. Argentina, Decision on Jurisdiction of 22 February 2006.

${ }^{39}$ UNCITRAL, National Grid plc v. The Argentine Republic, Decision on Jurisdiction, 20 June 2006, para. $53 \mathrm{ff}$.

${ }^{40}$ ICSID Case No. ARB/04/15, Telenor Mobile Communications A.S. v. Hungary, Award of 22 June 2006. See on this issue also Reinisch, International Centre for Settlement of Investment Disputes (ICSID), The Global Community: Yearbook of International Law and Jurisprudence 2006 (2007), 1806-1807.

${ }^{41}$ ICSID Case No. ARB/03/19, Suez, Sociedad General de Aguas de Barcelona S.A., and Vivendi Universal S.A. v. The Argentine Republic, and UNCITRAL, AWG Group Ltd. v. The Argentine Republic, Decision on Jurisdiction, 3 August 2006. 
investor-state arbitration only in case of disputes over the amount of compensation owing in the event of an expropriation or nationalization. By a majority of two-to-one the tribunal refused to allow the Belgian investors to invoke the Most-Favoured-Nation (MFN) clause in this agreement in an effort to "borrow" more favourable dispute settlement rules found in more recent bilateral investment treaties signed by Russia. ${ }^{42}$

23. Champion Trading Company, Ameritrade International, Inc., James T. Wahba, John B. Wahba, Timothy T. Wahba v. Egypt (2006). The tribunal came to the conclusion that the investor was not "in a like situation" to another investor with regard to whom he had invoked a violation of the MFN standard. ${ }^{43}$

24. Parkerings-Compagniet AS v. Lithuania (2007). In this case the claimants invoked their right to obtain MFN treatment in view of an alleged more favorable treatment of a competitor by the Lithuanian authorities. The treatment related to the denied renewal of a permit for environmental reasons and the impact on the local community. The tribunal did not deny that the MFN clause as such was applicable but came to the conclusion that the situation referred to was not governed by "like circumstances and thus the differential treatment seemed justified and was not contrary to the MFN clause."44

25. Société Générale v. Dominican Republic (2008). The claimant argued that the MFN provision of the France-Dominican Republic BIT should entitle the French firm to the more-favourable definition of investments in Central American Free Trade Agreement (CAFTA). However, the tribunal rejected this effort, holding that the MFN clause only extended to "treatment" accorded to investments, not to the definition of investment itself. In addition, the tribunal also accepted the DR Government's view that an exclusion clause in the BIT prevented the MFN clause from reaching into a free trade agreement such as the CAFTA. ${ }^{45}$

26. RosInvestCo UK Ltd. v. The Russian Federation (2007). A tribunal upheld jurisdiction in this case by allowing a British investor to invoke a wider dispute settlement clause from the BIT between Denmark and Russia. The UK-Soviet Union BIT precluded an examination of whether the claimant had, in fact, suffered expropriation as it limited investor-state arbitration to disputes over the amount of

\footnotetext{
${ }^{42}$ SCC Case No. 080/2004 (Belgium/Russia BIT), Berschader v. Russia, Award, 21 April 2006. See also Peterson, Investment Treaty News (ITN), 23 August 2006 (available online at http:// www.iisd.org/pdf/2006/itn_aug23_2006.pdf, (last visited 4 January 2009).

${ }^{43}$ ICSID Case No. ARB/02/9 (United States/Egypt BIT), Champion Trading Company, Ameritrade International, Inc., James T. Wahba, John B. Wahba, Timothy T. Wahba v. Egypt, Award, 27 October 2006. See also Reinisch, International Centre for Settlement of Investment Disputes (ICSID), The Global Community: Yearbook of International Law and Jurisprudence 2007 (2008), at III.4.

${ }^{44}$ ICSID Case No. ARB/05/8 (Norway/Lithuania BIT) Parkerings-Compagniet AS v. Lithuania, Award, 11 September 2007. For comments see Vis-Dunbar and Peterson, Lithuania victorious in dispute with Norwegian parking lot business, Investment Treaty News, September 28, 2007, 3.

${ }^{45}$ UNCITRAL, LCIA Case No. UN7927 (France/Dominican Republic BIT), Société Générale v. Dominican Republic, Preliminary Objections to Jurisdiction, 19 September 2008. See Peterson, Investment Arbitration Reporter, Vol. 1, No. 12, 9 October 2008.
} 
compensation or any other matter consequential of expropriation but which contained an MFN clause. ${ }^{46}$ The tribunal expressly left open the question whether an arbitration clause as such could be incorporated through reliance on an MFN clause. $^{47}$

27. L.E.S.I. S.p.A. et ASTALDI S.p.A. v. Algeria (2008). The claimant invoked the "fair and equitable treatment" clause not contained in the Italy-Algeria Agreement from another BIT, thanks to the MFN clause contained in this latter agreement. The tribunal accepted this argument but came to the conclusion that the standard imported this way was not violated. ${ }^{48}$

28. Wintershall Aktiengesellschaft v. Argentine Republic (2008). In this decision an ICSID tribunal ruled that a German investor could not invoke the MFN provision of the Germany-Argentina bilateral investment treaty in order to evade a treaty requirement that claims be pursued for 18 months in the Argentine courts before being subjected to international arbitration by invoking a dispute settlement provision without such a waiting period in the Argentina-US BIT. The same provision was interpreted differently in the case Siemens v. Argentina. ${ }^{49}$

\section{Specific Issues Addressed in Investor-State Arbitration}

\section{The Ejusdem Generis Principle}

The dynamic nature of the MFN clause is intended to operate only in situations where a treatment occurs in "like situations" or "like circumstances". 50 One can see it as a normal limitation of any non-discrimination rule as it exists in most if not all legal systems. When it comes to the application of the MFN clause in the basic treaty to invoke the applicability of a specific treatment provision in a third-party treaty this principle is normally referred to as the "ejusdem (or eiusdem) generis principle". It is normally understood to mean that the third-party treaty must, in principle, regulate the same subject-matter as the basic treaty, otherwise the specific treatment standard would be taken out of its context and thus not be accorded in "like circumstances" or in "like situations". No other rights can be claimed under a most-favoured-nation clause than those falling within the limits of the

\footnotetext{
${ }^{46}$ SCC Case No. Arb. V079/2005, RosInvestCo UK Ltd. v. The Russian Federation, Award on Jurisdiction, 28 October 2007.

${ }^{47}$ Para. 129.

${ }^{48}$ ICSID Case No. ARB/05/3 (Italy/Algeria BIT), L.E.S.I. S.p.A. et ASTALDI S.p.A. v. Algeria, Award, 12 November 2008.

${ }^{49}$ ICSID Case No. ARB/04/14 (Germany/Argentina BIT), Wintershall Aktiengesellschaft $v$. Argentine Republic, Award, 8 December 2008.

${ }^{50}$ For a typical example of the comparison of two situations, see ICSID Case No. ARB/05/ 8 (Norway/Lithuania BIT), Parkerings-Compagniet AS v. Lithuania, Award, 11 September 2007.
} 
subject-matter of the clause. Furthermore one can extend this principle to the "persons and things" covered by the standard which must be of the same category. ${ }^{51}$

So far, ascertaining the application of this principle has not given rise to controversial issues within investment cases. In reality, the ejusdem generis principle has been extensively discussed only by the ICSID Tribunals of the Maffezini and Suez cases. ${ }^{52}$ More recently the Wintershall Tribunal also referred to it. ${ }^{53}$ This can be explained by the fact that investors have normally invoked rules contained in third-party BITs under the MFN clause of a BIT (basic treaty). Even where the treaty does not specify that the MFN principle applies only to "like circumstances" or in "like situations", it can be considered as an inherent principle underlying the MFN principle. $^{54}$

An interesting example of a situation other than domestic where this question was discussed is a legal opinion by the Swiss Directorate of Public International Law, a unit of the Swiss Department of Foreign Affairs of $1994 .{ }^{55}$ In this case, a plaintiff invoked under the MFN clause contained in Article 4 of the Convention on Establishment and Legal Protection of $1927^{56}$ the procedural rights contained in the Convention of 16 September 1988 on jurisdiction and the enforcement of

\footnotetext{
${ }^{51}$ Ustor, Most Favoured Nation Clause, in: Encyclopaedia of Public International Law 3 (1997), p. 472. See also The Anglo-Iranian Oil Company (Jurisdiction) Case (United Kingdom vs Iran), 22 July 1952, ICJ Reports, 1952, p. 109 and Article 9 and 10 of the Draft Articles on MostFavoured-Nation Clauses (1978), International Law Commission, as available online at http:// untreaty.un.org/ilc/texts/instruments/english/draft\%20articles/1_3_1978.pdf (last visited on 4 January 2009).

${ }^{52}$ See Acconci, Most-Favoured Nation Treatment and International Law on Foreign Investment, in: Muchlinski/Ortino/Schreuer (eds.), The Oxford Handbook of International Investment Law, 2008, pp. 363-407. See, on the application of this principle with regard to the Maffezini and Plama cases, also McLachlan, Shore and Weiniger, International Investment Arbitration - Substantive Principles, 2007, pp. 254-257.

${ }^{53}$ ICSID Case No. ARB/04/14 (Germany/Argentina BIT), Wintershall Aktiengesellschaft v. Argentine Republic, Award, 8 December 2008. They refer to historic examples at Para 101: "[A]n interesting application of this principle has been mentioned by Prof. George Schwazenberger in an Article in the British Yearbook on International Law 1945 ("The Most-Favoured-Nation Standard in British State Practice", para. 96 at p. 108, footnote 6) It is the decision of the Umpire of the British-Venezuelan Mixed Claims Commission in the case of The Aroa Mines under the Protocol of February 13, 1903. The Umpire held that the relevant MFN Clause on which Great Britain relied and which extended to the administration of Justice only applied to rights before national courts "but not, as Great Britain had maintained, to the proceedings of the International Mixed Claims Commission, a restricted interpretation of an MFN Clause" (emphasis in original).

${ }^{54}$ See also with regard to the specific case of Swiss BITs: Schmid, Swiss Investment Protection Agreements: Most-Favoured-Nation Treatment and Umbrella Clauses, 2007, p. 43.

${ }^{55}$ Direction du droit international public, Avis du 11 mars 1994; reprinted in French in "Pratique suisse 1994, $\mathrm{N}^{\circ}$ 4.2” in: Revue suisse de droit international et de droit européen (1995), pp. 25 ff.; also reprinted in: Jurisprudence des autorités administratives de la Confédération (JAAC) no. 59.155; available online as http://www.vpb.admin.ch/deutsch/doc/59/59.155.html (last visited on 4 January 2009).

${ }^{56}$ Convention d'établissement et de protection juridique que la Suisse et la Grèce du 30 novembre 1927.
} 
judgments in civil and commercial matters (so-called Lugano Convention). ${ }^{57}$ The authority denied such a right, invoking the ejusdem generis principle as the two treaties did not have "the same objective".

Nevertheless, even where a Party invokes the clauses of another BIT through the MFN clause in a different BIT, this principle may play an important role. The Wintershall Tribunal most recently held that a correct interpretation of the term "treatment"

The question whether Article 3 [MFN Treatment] could apply to the dispute resolution clause in Article 10 [and specifically to the 18-month requirement stipulated in paragraph (2) thereof] has to be answered in the negative - not because 'treatment' in Article 3 may not include 'protection' of an investment by the investor adopting ICSID arbitration, but primarily because of the significance that has been attached by the Contracting States to the 18-month requirement in Article 10(2): it is part and parcel of Argentina's integrated 'offer' for ICSID arbitration. This 'offer' must be accepted by the investor on the same terms. Besides, it is wellestablished, in this branch of the law, that a most-favoured-nation clause can only attract matters belonging to the same category of subject as that to which the clause itself relates - the issue being determined in accordance with the intention of the Contracting Parties, deduced from a reasonable interpretation of the Treaty. But what is the category of subject (the genus) to which the 'treatment' mentioned in Article 3 relates? That is not mentioned in Article 3 - it can only be ascertained upon reading Article 3 along with Article 4 [Treatment]. ${ }^{59}$

\section{Explicit Descriptions of the Scope}

Some MFN clauses are very general in scope. A typical example is the clause in the Agreement between Spain and Argentina, which was at stake in the Maffezini decision. Article IV (2) of the Argentina-Spain BIT $^{60}$ is relatively open or unspecific with regard to the exact scope of the MFN clause:

In all matters subject to this Agreement, this treatment shall not be less favourable than that extended by each Party to the investments made in its territory by investors of a third country. ${ }^{61}$

Certain MFN clauses go further in their explicitness and define the types of situations in which the treatment is subject to the MFN standard. Article 1103 (Most-Favored-Nation Treatment) of the North American Free Trade Agreement

\footnotetext{
${ }^{57}$ At the time of the dispute, Greece was not yet a Party to this Convention.

${ }^{58}$ See next paragraph on the explicit description of the scope of an MFN clause.

${ }^{59}$ Para. 162.

${ }^{60}$ Signed in Buenos Aires on 3 October 1991; available in Spanish by UNCTAD on its "Investment Instruments Online" site: http://www.unctadxi.org/templates/DocSearch_779.aspx (last visited on 4 January 2009).

${ }^{61}$ English translation of the Spanish original ("En todas las material regidas por el presente Acuerdo, este tratamiento no será menos favorable que el otorgado por cada Parte a los inversiones realizadas en su territorio por inversores de un tercer país").
} 
(NAFTA) (which resembles very much Article 4 of the 2004 US Model BIT ${ }^{62}$ ) reads:

1. Each Party shall accord to investors of another Party treatment no less favorable than that it accords, in like circumstances, to investors of any other Party or of a non-Party with respect to the establishment, acquisition, expansion, management, conduct, operation, and sale or other disposition of investments.

2. Each Party shall accord to investments of investors of another Party treatment no less favourable than that it accords, in like circumstances, to investments of investors of any other Party or of a non-Party with respect to the establishment, acquisition, expansion, management, conduct, operation, and sale or other disposition of investments. [Emphasis added.]

This MFN treatment clause is particular - in comparison to those clauses concluded especially by most European states (at least until recently) - in so far as it includes besides the "management, conduct, operation, and sale or other disposition of investments" also the "establishment, acquisition, expansion" and thus extends MFN treatment to market access or establishment, i.e. rights normally related to the pre-establishment phase of foreign direct investment. While traditionally only the United States and Canada regularly included such market access rights, it is now very common for many states to include them into the general scope of the treatment standards of an agreement. ${ }^{63}$

Similarly, Article 40 Paragraph 1 (National Treatment and Most-FavouredNation Treatment) of the Investment Chapter in the EFTA-Singapore Free Trade Agreement reads:

Each Party shall accord to investors and investments of investors of another Party, in relation to the establishment, acquisition, expansion, management, conduct, operation and disposal of investments, treatment that is no less favourable than that which it accords in like situations to its own investors and their investments or to investors and their investments of any other State, whichever is more favourable. [emphasis added]

\footnotetext{
${ }^{62}$ Text made available online by the US Secretary of State at http://www.ustr.gov/assets/Trade Sectors/Investment/Model_BIT/asset_upload_file847_6897.pdf (last visited on 4 January 2009).

${ }^{63}$ See, for many examples from Canadian and US practice, Acconci, Most-Favoured Nation Treatment and International Law on Foreign Investment, in: Muchlinski/Ortino/Schreuer (eds.), The Oxford Handbook of International Investment Law, 2008, pp. 363-407, Sect. 3.1. with reference, e.g. to Canada-Latvia (1995), Article II (3); Canada-South Africa (1995), Article II (3); US-Nicaragua (1995), Article II (1); Canada-Egypt (1996), Article II (3); Canada-Panama (1996), Article II (3); Canada-Venezuela (1996), Article II (3); Canada-Thailand (1997), Article II (3); US-Azerbaijan (1997), Article II (1); US-Jordan (1997), Article II (1); US-Bahrain (1999), Article 2 (1); US-El Salvador (1999), Article II (1). See also the 2004 Canadian Model BIT, Article 4, and the 2004 US Model BIT, Article 4. All made available by UNCTAD on its "Investment Instruments Online" site, http://www.unctadxi.org/templates/DocSearch_779.aspx (last visited on 4 January 2009). See also Salacuse, Do BITs Really Work? An Evaluation of Bilateral Investment Treaties and Their Grand Bargain, Harvard International Law Journal 46 (2005) p. 67 (93-94).
} 
Here again we see that the extension of the MFN clause is limited to certain operations (including pre-establishment rights) and only applies in "like situations". Similarly NAFTA speaks of "like circumstances". Other variations of the MFN clause may not specify at all to what kinds of treatment they apply, i.e. specific standards, treatment in general or any provision of the treaty. Article 3 (first part) of the Treaty between the Federal Republic of Germany and the Co-operative Republic of Guyana concerning the Encouragement and Reciprocal Protection of Investments of 6 December $1989^{64}$ reads:

Neither Contracting Party shall subject investments in its territory owned or controlled by nationals or companies of the other Contracting Party to treatment less favourable than it accords to investments of its own nationals or companies of any third State.

Neither Contracting Party shall subject nationals or companies of the other Contracting Party, as regards their activity in connection with investments in its territory, to treatment less favourable than it accords to its own nationals or companies of any third State. ... [emphasis added]

More specifically when it comes to the treatment of investors, Article 4 of the 1995 Swiss Model BIT ${ }^{65}$ provides:

1. Each Contracting Party shall in its territory accord investments or returns of investors of the other Contracting Party treatment not less favourable than that which it accords to investments or returns of its own investors or to investments or returns of investors of any third State, whichever is more favourable to the investor concerned.

2. Each Contracting Party shall in its territory accord investors of the other Contracting Party, as regards the management, maintenance, use, enjoyment or disposal of their investments, treatment not less favourable than that which it accords to its own investors or investors of any third State, whichever is more favourable to the investor concerned.

Similarly during the negotiations for a Central America-Dominican RepublicUnited States Free Trade Agreement (CAFTA) in 2004, the parties had included at some point a footnote in the draft text with the following text:

[t]he Most-Favored-Nation Treatment Article of this Agreement is expressly limited in its scope to matters 'with respect to the establishment, acquisition, expansion, management, conduct operation and sale or other dispositions of investments.' The Parties share the understanding and intent that this clause does not encompass international dispute resolution mechanisms such as those contained in Section $\mathrm{C}$ of this chapter, and therefore could not reasonably lead to a conclusion similar to that of the Maffezini case.

\footnotetext{
${ }^{64}$ As made available by UNCTAD on its "Investment Instruments Online" site, http://www. unctadxi.org/templates/DocSearch_779.aspx (last visited on 4 January 2009).

${ }^{65}$ As made available by UNCTAD on its "Investment Instruments Online" site, http://www. unctadxi.org/templates/DocSearch_779.aspx (last visited on 4 January 2009).
} 
The footnote was to be eliminated before the conclusion of the negotiations but its insertion in 2004 was specifically intended to make it part of the negotiating history. To the United States this approach obviously seems to be a way to prevent a "Maffezini-like" interpretation of the MFN clauses contained in its agreements without leading to an unwanted watering-down of the provision. ${ }^{66}$

Furthermore, on 30 May 2006 the European Commission (DG Trade) presented an Issue Paper for the attention of the EC's so-called 133 Committee in view of its future competence to negotiate investment treaties on behalf of the European Community, thus taking over this competence from the Member States, as envisaged in the most recent proposals for treaty amendments. In this paper the Commission suggested with regard to the inclusion of an appropriate MFN clause in future agreements:

The scope of application of the MFN clause is focused and limited to establishment, thus clearly signalling that it could not extend to BIT provisions on expropriation and dispute settlement.

It appears necessary to exclude from the benefit of this clause most deep-integration agreements the EU concludes (i.e. to exclude granting to third countries the advantages resulting from - for instance - the EU-Balkans Stabilisation and Association Agreements that could lead at a later stage to EU accession). To that aim, the classical regional economic integration organisation (REIO) clause needs to be adjusted to avoid a carve-out from the scope of MFN treatment of any FTA, which would be counter-productive.

Here again, this approach is fully consistent with WTO commitments of the EU under the GATS, since the latter contains an MFN provision of general application. It is also consistent with existing EU agreements with third countries that already contain an MFN provision (examples: Article 30 of the EU-Jordan Association Agreement; Article 48 of the Agreement EU-FYROM). ${ }^{67}$

Finally, Switzerland has very recently partly changed its practice regarding the language related to MFN treatments in its BITs in what seems a clear reaction to the Maffezini case law. In the agreement with Colombia signed on 17 May 2006, ${ }^{68}$ the parties have included an Annex which reads:

\footnotetext{
${ }^{66}$ See also Peterson, Investment Law and Policy Weekly News Bulletin, 6 February 2004, available online at www.iisd.org/pdf/2004/investment_investsd_feb6_2004.pdf (last visited on 4 January 2009) and American Society of International Law, International Law In Brief, 6 February 2004, available online at http://www.asil.org/ilib/ilib0703.htm (last visited on 4 January 2009).

${ }^{67}$ The text was made available online at www.iisd.org/pdf/2006/tas_upgrading_eu.pdf (last visited 4 January 2009); see on this issue also Vis-Dunbar/Peterson, European Commission makes another play for power to negotiate investment pacts, Investment Treaty News (ITN), 9 July 2006, para. 6; available online at http://www.investmenttreatynews.org/content/archives.aspx (last visited on 4 January 2009).

${ }^{68}$ Swiss Federal Council, Despatch to the Swiss Parliament regarding the Agreements on the Promotion and Protection of Investments with Serbia and Montenegro, Guyana, Azerbaijan, Saudi Arabia and Colombia, September 22, 2006, Official Gazette (Bundesblatt) (2006) 8455 ff., 8460 available online in German at http://www.admin.ch/ch/d/ff/2006/8455.pdf (last visited on 4 January 2009).
} 
For greater certainty, it is further understood that the most favourable nation treatment (...) does not encompass mechanisms for the settlement of investment disputes provided for in other international agreements concluded by the Party concerned. ${ }^{69}$

\section{Specifically Negotiated Provisions}

The use of the MFN Clause to invoke the applicability of treaty norms between one Party of the Treaty at stake and a third State is subject to the condition that the two treaties do create like circumstances, i.e. they must regulate the same subject matter. ${ }^{70}$ In the Tecmed arbitral award, ${ }^{71}$ the arbitral tribunal held that the MFN clause could not be used to invoke those provisions of a Treaty with a third State that were clearly the result of a particular negotiating situation with this third State and thus constituted part of a specific "package deal" made up of specific rights and obligations ("... .core matters that must be deemed to be specifically negotiated by the Contracting Parties"...). ${ }^{72}$

In the view of the Tecmed arbitral tribunal, the very nature of these provisions makes them unfit for being invoked by third states under an MFN clause. ${ }^{73}$ The provision providing for retroactive application of a BIT to investments made before the entry into force of the BIT was considered to be such a clause that had only been granted to the respective treaty partner in view of the specific negotiating situation and could thus not be invoked by an investor under another BIT.

Already the Maffezini Tribunal had held that "the beneficiary of the [MFN] clause should not be able to override public policy considerations that the contracting parties might have envisaged as fundamental conditions for their acceptance of the agreement in question". ${ }^{74}$ According to the tribunal this would apply, for instance:

(a) Where a State has conditioned its consent to arbitration on the exhaustion of local remedies;

(b) Where a BIT contains a "fork-in-the-road" clause according to which a choice between domestic or international courts or tribunals becomes irreversible once made;

\footnotetext{
${ }^{69}$ Protocol to the BIT (note 68) with Colombia ad Article 4 para. 2.

${ }^{70}$ See also Herdegen, Internationales Wirtschaftsrecht, (6th ed.) 2007, p. 221.

${ }^{71}$ ICSID Case No. ARB/AF/00/2, Technicas Medioambientales Tecmed S.A. v. Mexico, Award, 29 May 2003.

${ }^{72}$ ICSID Case No. ARB/AF/00/2, Technicas Medioambientales Tecmed S.A. v. Mexico, Award, 29 May 2003, para. 69.

${ }^{73}$ See also Herdegen, Internationales Wirtschaftsrecht, (6th ed.) 2007, p. 221.

${ }^{74}$ ICSID Case No. ARB/97/7, Maffezini v. Spain, Decision on Jurisdiction, 24 January 2000, para. 62 .
} 
(c) Where a particular forum such as ICSID or NAFTA has been chosen;

(d) If the parties have agreed to a highly institutionalized system of arbitration that incorporates precise rules of procedure, such as NAFTA. ${ }^{75}$

However, the Maffezini Tribunal considered a mere requirement to first resort to domestic courts during a period of 18 months did not reflect a fundamental question of public policy which would have limited the scope of the MFN clause. ${ }^{76}$

This argument was also important in the most recent Wintershall arbitral award. Here the 18-month time limit was considered an important element of the consent to arbitration given by the State Parties. ${ }^{77}$

\section{Relevance for Procedural Provision in General}

Over all, the main question in the Maffezini ${ }^{78}$ arbitral award and later similar decisions remained whether the MFN clause applied only to substantive rules (treatment provisions) or also to procedural rules, such as the rules relating to dispute settlement or application ratione temporis (retrospective application) or ratione materiae (umbrella clauses) under a $\mathrm{BIT}^{79}$

Those authors and arbitrators opposed to applying the MFN clause to procedural guarantees, in particular dispute settlement, mostly consider such an application contrary to the intention of the Contracting Parties. ${ }^{80}$ In the Plasma v. Bulgaria case, the arbitral tribunal stated accordingly:

[A]n MFN provision in a basic treaty does not incorporate by reference dispute settlement provisions in whole or in part set forth in another treaty, unless the MFN provision in the basic treaty leaves no doubt that the Contracting Parties intended to incorporate them ${ }^{81}$

\footnotetext{
${ }^{75}$ ICSID Case No. ARB/97/7, Maffezini v. Spain, Decision on Jurisdiction, 24 January 2000, para. 63.

${ }^{76}$ See Reinisch, Maffezini v. Spain Case, in: Encyclopaedia of Public International Law — EPIL, forthcoming 2010.

${ }^{77}$ ICSID Case No. ARB/04/14 (Germany/Argentina BIT), Wintershall Aktiengesellschaft v. Argentine Republic, Award, 8 December 2008.

${ }^{78}$ ICSID Case No. ARB/97/7, Maffezini v. Spain, Decision on Jurisdiction, 24 January 2000, paras. $53 \mathrm{ff}$.

${ }^{79}$ The question as to whether the MFN treatment obligation applied also to procedural standards besides substantive treatment provisions has also arisen in the framework of trade, more specifically in relation to the GATT of 1947 in the case United States - Section No. 337 of the Tariff Act of 1930, see below Section IV.

${ }^{80}$ See Herdegen, Internationales Wirtschaftsrecht, (6th ed.) 2007, p. 221 with reference to the arbitral awards in ICSID Case No. ARB/02/13, Salini Costruttori S.p.A and Italstrade S.p.A v. The Hashemite Kingdom of Jordan, Decision on Jurisdiction, 29 November 2004, paras. $102 \mathrm{ff}$. and ICSID Case No. ARB/03/24, Plama Consortium Ltd. v. Bulgaria, Decision on Jurisdiction, 8 February 2005, para. 223. Most recently also in ICSID Case No. ARB/04/14 (Germany/ Argentina BIT), Wintershall Aktiengesellschaft v. Argentine Republic, Award, 8 December 2008.

${ }^{81}$ ICSID Case No. ARB/03/24, Plama Consortium Ltd. v. Bulgaria, Decision on Jurisdiction, 8 February 2005, para. 223.
} 
Also the recent steps by Canada, the US and the EC to limit the scope of their MFN clauses included in BITs seem to hint in this direction. ${ }^{82}$ At the same time, many arbitrators and authors seem to consider such limitation unnecessary or at least not supported by the treaty language used in the past. The Maffezini tribunal openly rejected Spain's argument that "matters" can only be understood to refer to substantive matters or material aspects of the treatment granted to investors and not to procedural or jurisdictional questions. Relying on international precedents and considering the broad wording of the MFN clause which refers to "all matters subject to this Agreement", the tribunal emphasised that dispute settlement provisions in BITs were "essential to the protection of the rights envisaged under the pertinent treaties; they are also closely linked to the material aspects of the treatment accorded". 83 Similarly Gaillard considers it logical to include dispute settlement provisions among the types of treatment subject to MFN. ${ }^{84}$ Also several other authors seem favourable to including procedural rules as long as this seems openly excluded by the wording of a treaty or is evident from the context when interpreting the treaty at stake. ${ }^{85}$

It is interesting to observe that generally arbitral tribunals were only willing to let the claimant borrow more favourable dispute settlement provisions in cases involving BITs concluded by Argentina and on the question of a mandatory waiting period. This approach developed in Maffezini was even expanded in Siemens v. Argentina (2004) where again the waiting period of 18 months was equally avoided in this way. Other cases affirming the possibility of getting rid of a waiting period through importation of a different dispute settlement provision not containing this requirement into a BIT are Gas Natural v. Argentina (2005), Camuzzi v. Argentina (2005), ${ }^{86}$ National Grid plc v. Argentina (2006), ${ }^{87}$ as well as in Suez,

\footnotetext{
${ }^{82}$ See section immediately before this one.

${ }^{83}$ ICSID Case No. ARB/97/7, Maffezini v. Spain, Decision on Jurisdiction, 24 January 2000, para. 55 as summarized by Reinisch, Maffezini v. Spain Case, Encyclopaedia of Public International Law - EPIL, forthcoming 2010.

${ }^{84}$ See Gaillard, Chronique des sentences arbitrales, Journal du Droit International 132 (2005), pp. 135 ff. (163): "Lorsque la clause est rédigée en des termes très généraux, tout laisse à penser que l'intention des rédacteurs du traité était bien de lui permettre de jouer à l'égard de tous les bénéfices que l'Etat d'accueil serait susceptible d'accorder aux ressortissants d'Etats tiers. Or force est de constater que l'accès à un mécanisme efficace et neutre de règlement des différends ... est bien l'un des bénéfices les plus importants, sinon le plus important, susceptible de résulter du droit contemporain de la protection des investissements". Gaillard, Establishing Jurisdiction through a Most-Favored-Nation Clause, New York Law Journal 203 (2005), p. 105.

${ }^{85}$ See also Bernardini, Investment Arbitration under the ICSID Convention and BITs, in: Aksen et al. (eds.), Liber Amicorum in Honour of Robert Briner, 2005, pp. 95 ff.; Schreuer, The Dynamic Evolution of the ICSID System, 2006, p. 9. See also Schmid, Swiss Investment Protection Agreements: Most-Favoured-Nation Treatment and Umbrella Clauses, 2007, p. 43 and p. 46.

${ }^{86}$ ICSID Case No. ARB/03/2, Camuzzi International S.A. v. Argentina, Decision on Objections to Jurisdiction of 11 May 2005, para. 121. See for details Acconci, Most-Favoured Nation Treatment and International Law on Foreign Investment, in: Muchlinski/Ortino/Schreuer (eds.), The Oxford Handbook of International Investment Law, 2008, pp. 363-407, Sect. 5.1.

${ }^{87}$ UNCITRAL, National Grid plc v. The Argentine Republic, Decision on Jurisdiction, 20 June 2006, para. $53 \mathrm{ff}$.
} 
Sociedad General de Aguas de Barcelona S.A., and Vivendi Universal S.A. and $A W G$ Group Ltd. v. Argentina (2006) ${ }^{88}$ All these cases involve the non-compliance with the waiting periods provided in some of Argentina's BITs. Only in Wintershall Aktiengesellschaft v. Argentine Republic (2008) did the ICSID tribunal deny the implicit waiver of the 18 -month waiting period by reliance on the MFN clause. ${ }^{89}$

In Salini v. Jordan (2004), ${ }^{90}$ in Plama v. Bulgaria (2005), ${ }^{91}$ in Telenor v. Hungary (2006), and Berschader v. Russia (2006), ${ }^{92}$ however, the respective ICSID tribunals came to the conclusion that the applicable MFN clauses did lend themselves to widening the substantive scope of the dispute settlement method specifically chosen in a selected BIT. ${ }^{93}$ Only in RosInvestCo UK Ltd.v. The Russian Federation (2007) ${ }^{94}$ did the tribunal uphold jurisdiction in this case by allowing a British investor to invoke a dispute settlement clause with a wider substantive scope. This seems so far the only existing decision where a tribunal accepted the import of a procedural aspect of a dispute settlement provision other than the waiting period.

\section{Summary Analysis}

In recent years arbitrators and commentators have been focusing on the question whether the MFN treatment clause of BITs applies to all types of treatment or whether it is limited to certain kinds of treatment. For some the case law of various arbitral tribunals diverges heavily. Others have tried to distinguish between the different arbitral awards and to develop a coherent theory taking into account the wording and context of specific MFN clauses. These theories which try to establish under what circumstances MFN treatment should have a broad scope (possibly including consent to arbitration, procedural aspects of dispute settlement etc.), and when MFN does not apply do not, however, seem extremely convincing. Therefore more and more States seem to prefer a clear exclusion of procedural provisions, especially dispute settlement. They do so by stating the exception in an appropriate way in the text or the negotiating history of the newer agreements.

\footnotetext{
${ }^{88}$ ICSID Case No. ARB/03/19, Suez, Sociedad General de Aguas de Barcelona S.A., and Vivendi Universal S.A. v. The Argentine Republic, and UNCITRAL, AWG Group Ltd. v. The Argentine Republic, Decision on Jurisdiction, 3 August 2006.

${ }^{89}$ ICSID Case No. ARB/04/14 (Germany/Argentina BIT), Wintershall Aktiengesellschaft v. Argentine Republic, Award, 8 December 2008.

${ }^{90}$ ICSID Case No. ARB/02/13, Salini Costruttori S.p.A and Italstrade S.p.A v. The Hashemite Kingdom of Jordan, Decision on Jurisdiction, 29 November 2004.

${ }^{91}$ ICSID Case No. ARB/03/24, Plama Consortium Ltd. v. Bulgaria, Decision on Jurisdiction, 8 February 2005.

${ }^{92}$ SCC Case No. 080/2004 (Belgium/Russia BIT), Berschader v. Russia, Award, 21 April 2006.

${ }^{93}$ See Reinisch, Maffezini v. Spain Case, in: Encyclopaedia of Public International Law - EPIL, forthcoming 2010.

${ }^{94}$ SCC Case No. Arb. V079/2005, RosInvestCo UK Ltd. v. The Russian Federation, Award on Jurisdiction, 28 October 2007.
} 


\section{Application to Like Circumstance}

The case law relating to the mere application of the MFN standard to the treatment of arbitrators in "like circumstances" or "like situations" (without reference to another BIT) are rather rare and do not seem to cause major problems. In both Champion Trading Company, Ameritrade International, Inc., James T. Wahba, John B. Wahba, Timothy T. Wahba v. Egypt (2006) ${ }^{95}$ and Parkerings-Compagniet $A S v$. Lithuania $(2007)^{96}$ the tribunals accepted the applicability of the MFN clause but came to the conclusion that the investors were not "in a like situation" or that the situation was not governed by "like circumstances" and thus the differential treatment seemed justified and was not contrary to the MFN clause."97

\section{Borrowing Substantive Treatment Standards}

To invoke treatment standards from another BIT can be more difficult. Here the question as to whether a differently worded standard in another agreement results in more favorable treatment can be controversial. ${ }^{98}$ To invoke specific substantive standards such as "fair and equitable treatment", "full protection and security", the prohibition of "unreasonable and discriminatory measures", the "obligation to grant necessary permits" 99 or "the remittance of capital transfers" 100 in the absence of such standards or clearly less advantageous provisions in the agreement containing the MFN clause, however, seems relatively easier. ${ }^{101}$ This can also be said for the

\footnotetext{
${ }^{95}$ ICSID Case No. ARB/02/9 (United States/Egypt BIT), Champion Trading Company, Ameritrade International, Inc., James T. Wahba, John B. Wahba, Timothy T. Wahba v. Egypt, Award, 27 October 2006.

${ }^{96}$ ICSID Case No. ARB/05/8 (Norway/Lithuania BIT), Parkerings-Compagniet AS v. Lithuania, Award, 11 September 2007.

${ }^{97}$ In ICSID Case No. ARB/03/29, Bayindir Insaat Turizm Ticaret Ve Sanayi A.Ş. v. Pakistan, Decision on Jurisdiction of 14 November 2005; the applicability of the MFN clause to alleged discrimination in a tendering procedure was not ruled out.

${ }^{98}$ ICSID Case No. ARB/87/3, AAPL v. Sri Lanka, Award of 27 June 1990, para. 54.

${ }^{99}$ ICSID Case No. ARB/01/7, MTD Equity Sdn. Bhd. and MTD Chile S.A. v. Republic of Chile, Award, 25 May 2004, para. 103.

${ }^{100}$ ICSID Case No. ARB/03/9, Continental Casualty Co. v. Argentina, Decision on Jurisdiction of 22 February 2006.

${ }^{101}$ ICSID Case No. ARB (AF)/00/1 (NAFTA), ADF Group Inc. v. United States, Award, 9 January 2003, paras. 193ff; ICSID Case No. ARB/01/7, MTD Equity Sdn. Bhd. and MTD Chile S.A. v. Republic of Chile, Award, 25 May 2004, para. 103; ICSID Case No. ARB/03/29, Bayindir Insaat Turizm Ticaret Ve Sanayi A.Ş. v. Pakistan, Decision on Jurisdiction of 14 November 2005; ICSID Case No. ARB/03/9, Continental Casualty Co. v. Argentina, Decision on Jurisdiction of 22 February 2006; ICSID Case No. ARB/05/3 (Italy/Algeria BIT), L.E.S.I. S.p.A. et ASTALDI S.p.A. v. Algeria, Award, 12 November 2008.
} 
importation of the inclusion of contractual clauses through so-called "umbrella clauses". 102

\section{Borrowing Provisions Defining the Scope of an Agreement}

However, specific exceptions, expressly contained in the agreement containing the MFN clause, seem less likely to be avoided by reference to another BIT not containing them in view of the ejusdem generis rule. ${ }^{103}$ When it comes to the definitions of "investment" and "investors" certain tribunals have refused to regard such issues as an aspect of treatment, ${ }^{104}$ which does not necessarily imply that future tribunals will admit borrowing such provisions in cases where the MFN clause is worded more openly. At least one tribunal, however, has denied the possibility of importing the retroactive application of substantive standards as contained in a treaty with a third party "because it deem[ed] that matters relating to the application over time of the Agreement [...] due to their significance and importance, go to the core of matters that must be deemed to be specifically negotiated by the Contracting Parties". ${ }^{105}$

\section{Borrowing Dispute Settlement Provisions}

Most decisions on the MFN clause definitely relate to the question whether more favourable dispute settlement provisions can be borrowed. Here the Maffezini award of $2004^{106}$ is at the beginning of an ongoing debate by allowing - in view of the text of the MFN clause concerned and with certain caveats - such an importation in the case at stake (waiver of 18-month waiting period). It was followed in cases against Argentina with regard to the mandatory waiting period by an important number of tribunals. The only true exception is the recent Wintershall Aktiengesellschaft v. Argentine Republic (2008), where the ICSID tribunal

\footnotetext{
${ }^{102}$ ICSID Case No. ARB/01/7, MTD Equity Sdn. Bhd. and MTD Chile S.A. v. Republic of Chile, Award, 25 May 2004, para. 103, and ICSID Case No. ARB/03/3, Impregilo S.p.A. v. Pakistan, Decision on Jurisdiction of 22 April 2005, para. 223.

${ }^{103}$ ICSID Case No. ARB/01/8, CMS Gas Transmission Co. v. Argentina, Award of 20 April 2005, para. 377, and UNCITRAL, LCIA Case No. UN7927 (France/Dominican Republic BIT), Société Générale v. Dominican Republic, Preliminary Objections to Jurisdiction, 19 September 2008.

${ }^{104}$ UNCITRAL, LCIA Case No. UN7927 (France/Dominican Republic BIT), Société Générale v. Dominican Republic, Preliminary Objections to Jurisdiction, 19 September 2008.

${ }^{105}$ ICSID Case No. ARB/AF/00/2, Technicas Medioambientales Tecmed S.A. v. Mexico, Award, 29 May 2003, para. 69.

${ }^{106}$ ICSID Case No. ARB/97/7, Maffezini v. Spain, Decision on Jurisdiction, 24 January 2000, paras. $53 \mathrm{ff}$.
} 
denied the implicit waiver of the 18-month waiting period by reliance on the MFN clause. $^{107}$

However, when it comes to widening the scope of dispute settlement provisions the awards analyzed in this contribution have all rejected the borrowing of a wider scope from a different BIT, just as arbitral tribunals have normally rejected the widening of the scope of a BIT in general by relying on an MFN clause. Here, the decision in RosInvestCo UK Ltd. v. The Russian Federation (2007) ${ }^{108}$ seems to be the notable exception.

It seems clear from the analysis just undertaken that it is in particular the questions relating to the applicability of the MFN clause to the dispute settlement clauses contained in BITs with third parties that still needs clarification whereas the other aspects treated in this article seem rather governed by a coherent case law so far. This is not to say that the distinction which has been developed in practice by arbitral tribunals is perfectly logical and coherent. Possibly the view expressed by certain authors who argue that either all aspects of dispute settlement ${ }^{109}$ or none should be subject to the MFN clause will influence further developments in this field.

\footnotetext{
${ }^{107}$ ICSID Case No. ARB/04/14 (Germany/Argentina BIT), Wintershall Aktiengesellschaft v. Argentine Republic, Award, 8 December 2008.

${ }^{108}$ SCC Case No. Arb. V079/2005, RosInvestCo UK Ltd. v. The Russian Federation, Award on Jurisdiction, 28 October 2007.

${ }^{109}$ See Gaillard, Chronique des sentences arbitrales, Journal du Droit International 132 (2005) pp. $135 \mathrm{ff}$. (163): "Lorsque la clause est rédigée en des termes très généraux, tout laisse à penser que l'intention des rédacteurs du traité était bien de lui permettre de jouer à l'égard de tous les bénéfices que l'Etat d'accueil serait susceptible d'accorder aux ressortissants d'Etats tiers. Or force est de constater que l'accès à un mécanisme efficace et neutre de règlement des différends ... est bien l'un des bénéfices les plus importants, sinon le plus important, susceptible de résulter du droit contemporain de la protection des investissements"; Gaillard, Establishing Jurisdiction through a Most-Favored-Nation Clause, New York Law Journal 233 (2005), p. 105; Bernardini, Investment Arbitration under the ICSID Convention and BITs, in: Aksen et al. (eds.), Liber Amicorum in Honour of Robert Briner, 2005, p. 95; Schreuer, The Dynamic Evolution of the ICSID System, 2006, p. 9; Schmid, Swiss Investment Protection Agreements: Most-Favoured-Nation Treatment and Umbrella Clauses, 2007, p. 43.
} 